\title{
KINERJA PEGAWAI DALAM MENINGKATKAN PELAYANAN DI DINAS PENANAMAN MODAL DAN PELAYANAN TERPADU SATU PINTU KOTA PALANGKA RAYA
}

\author{
Performance officer in improving service at the capital investment and integrated \\ services one door city Palangka Raya
}

\section{Mita Sari'}

Dessy Kumalasari²

\section{Universitas Muhammadiyah Palangkaraya, Palangka Raya, Central Kalimantan, Indonesia}

email:

mitasyaja@gamail.com

\section{Kata Kunci:}

Kualitas

Kinerja

Pelayanan

PTSP

\section{Keywords:}

Quality

Performance

Service

PTSP

\section{Accepted \\ Februari 2020}

Published

April 2020

\begin{abstract}
Abstrak
Kualitas kinerja merupakan salah satu masalah yang tidak jauh bersangkutpaut terhadap pelayanan. Bagi masyarakat pelayanan adalah hal yang terjadi dan didapatkan hampir setiap hari. Pelayanan yang baik sangat berpengaruh terhadap suatu kualitas kinerja suatu pegawai dalam suatu organisasi. Seperti yang kita ketahui kinerja pegawai dikantor penanaman modal dan pelayanan terpadu satu pintu Kota Palangkaraya masih kurang karena dari pegawainya kekurangan sumber daya manusia sehingga dari segi pelayanan belum maksimal. Tujuan penelitian ini untuk mengetahui bagaimana kinerja pegawai dalam meningkatkan pelayanan dikantor penanaman modal dan pelayanan terpadu satu pintu Kota Palangkaraya.
\end{abstract}

Metode penelitian yang digunakan adalah kualitatif, penelitian ini menggunakan Teori Fuad Mas'ud yang didalamnya terdapat kualitas, kuantitas, ketepatan waktu, efektivitas, dan kemitmen kerja. Teknik pengumpulan data dalam penelitian ini yaitu observasi, wawancara, dokumentasi.

Hasil penelitian dapat ditarik kesimpulan bahwa Kinerja pegawai dalam meningkatkan pelayanan di DPM-PTSP Kota Palangkaraya masih belum optimal, dilihat dari lima indikator yaitu Kualitas, Kuantitas, Ketepatan Waktu, Efektivitas, dan Komitmen Kerja. Faktor-faktor kendala yang dapat mengahmbat jalannya pelayanan diantaranya, sumber daya manusia atau pegawainya yang kurang terutama dalam bidang pelayanan yang dibuktikan dari pegawai kurang menguasai bidang pelayanan dan keterlambatan waktu yang diberikan dalam menjalankan tugasnya banyak yang tidak sesuai. Selain faktor penghambat ada juga faktor pendukung yaitu saling memberikan semangat dan saling menyemangit antar pegawai dan menjalankan tugasnya berbagi karena kurangya sumber daya manusia tadi dapat saling membantu dalam menjalankan tugasnya dan menutupi kekurangan dari pekerjaan yang belum selesai serta berusaha memberikan pelayanan yang terbaik.

\footnotetext{
Abstract

Quality of performance is one of the problems that is not far from the service. For the Service society is the thing that happens and is obtained almost every day. Good service greatly affects the quality of performance of an employee in an organization. As we know the performance of employees at the Office of Investment and integrated service one door of the city of Palangkaraya still less because of its employees lack of human resources so in terms of service is not maximized. The purpose of this research is to know how employees are performing in improving the office of Investment and Integrated services at one door of Palangkaraya city.

The research method used is qualitative, this study uses the theory of Fuad Mas'ud which contains quality, quantity, timeliness, effectiveness, and kemitmen work. The data collection techniques in this study are observations, interviews, documentation.

The results of the research can be concluded that the performance of employees in improving the service at DPM-PTSP Palangkaraya city is still not optimal, seen from five indicators namely quality, quantity, timeliness, effectiveness, and work commitments. Obstacle factors that can mengahmbat the way of service, among others, human resources or employees who are less particularly in the field of service that is evidenced by employees lacking control of the field of service and the delay of time given in carrying out its duties are not appropriate. In addition to the inhibitory factor there are also supporting factors that are encouraging and mutually encouraging each other and carrying out their duties to share because the ability of human resources can help each other in carrying out their duties and to cover the lack of unfinished work and try to provide the best service.
} 


\section{PENDAHULUAN}

Pada era globalisasi seperti sekarang bangsa Indonesia dapat merasakan peluang maupun tantangan tanpa adanya batasan. Salah satu peluang yang dirasakan yaitu mudahnya menyerap informasi dengan menggunakan teknologi yang semakin maju dan berkembang dan tantangannya dalam suatu organisasi yaitu menggunakan informasi serta teknologi yang dapat mewujudkan kinerja menjadi lebih baik. Secara umum masyarakat selalu menggunakan jasa pelayanan dalam setiap kepentingannya sehari-hari. Hal itu membuat setiap organisasi atau lembaga memberikan jasa yang cenderung menawarkan pelayanan yang lebih baik dengan kualitas kinerja pegawai yang bekerja secara profesional.

Bagi bangsa Indonesia tuntutan terhadap kinerja yang baik perlu menggunakan usaha yang sungguh-sungguh untuk dapat mewujudkan dan menciptakan kualitas kinerja yang masih belum menunjukkan kinerja yang tinggi. Hal tersebut ditandai dengan rendahnya kualitas pelayanan yang diberikan oleh birokrat kepada masyarakat dan masalah ini dituding menjadi salah satu faktor penyebab negara kita terpuruk sampai saat ini.

Seperti yang kita ketahui, kualitas kinerja pegawai dalam memberikan pelayanan banyak yang masih kurang atau tidak sesuai prosedur. Pegawai masih banyak kurang kesadaran terhadap tugasnya masing-masing yang membuat hasil kerjanya terjadi kesalahan atau kurang tepatnya hasil kerja. Selain itu membuat pelayanan yang didapatkan masyarakat tidak sesuai standar.

Kualitas kinerja merupakan salah satu masalah yang tidak jauh bersangkutpaut terhadap pelayanan. Bagi masyarakat pelayanan adalah hal yang dirasakan setiap hari dan lumrah. Pelayanan yang baik sangat berpengaruh terhadap kualitas kinerja suatu pegawai dalam suatu organisasi. Karena pelayanan juga dapat dinilai masyarakat sebagai penentu baik buruknya kualitas kinerja para pegawai. Karena masyarakat semakin kritis terhadap tuntutan kualitas layanan yang menunjukkan karakter masyarakat kita dewasa dan telah memiliki sikap mandiri, terbuka dan mampu berdemokrasi. Hal ini berarti bahwa pelayanan semakin hari semakin bertambah dan harus lebih ditingkatkan kualitasnya terutama dari kinerja pegawainya itu sendiri.

Pemberian pelayanan yang memenuhi standar yang telah ditetapkan memang menjadi bagian yang perlu dicermati. Saat ini masih sering dirasakan bahwa kualitas pelayanan minimum sekalipun masih jauh dari harapan masyarakat. Yang lebih memprihatinkan lagi, masyarakat hampir sama sekali tidak memahami secara pasti tentang pelayanan yang seharusnya diterima dan sesuai dengan prosedur pelayanan yang baku oleh pemerintah. Masyarakat pun enggan mengadukan apabila menerima pelayanan yang buruk,bahkan hampir pasti mereka pasrah menerima layanan seadanya.

Pelayanan yang berkualitas sering kali sulit untuk dicapai karena para pegawai tidak selalu memahami bagaimana cara memberikan pelayanan yang baik. Maka dari itu dalam membangun kualitas kinerja pegawai yang efektif dan efisien diperlukan waktu untuk memikirkan bagaimana mencapai kesatuan kerjasama sehingga mampu meningkatkan kepercayaan masyarakat. Maka dari itu diperlukan otonomi dan kebebasan dalam mengalokasikan sumber daya membuat pedoman pelayanan, tujuan, serta target kinerja yang jelas dan terukur.

Adapun proses pelayanan di PTSP yang banyak dikeluhkan masyarakat sebagai pelayanan yang tidak terbuka karena dalam pelayanannya banyak kinerja atau pegawai tidak menjalankan sesuai prosedur. Salah satu permasalahan yang terjadi adalah ketika masyarakat membuat IMB, pada saat memasukan berkas yang seharusnya berkas yang yang paling bawah terlebih dahulu dikerjakan karena lebih awal dimasukan akan tetapi yang dikerjakan adalah 
berkas yang paling atas dan ada juga berkas titipan dari punya kerabat ata keluarga.

Dari permasalahan tersebut dapat dikatakan bahwa Dinas PTSP tidak menjalankan kinerja sesuai prosedur kualitas kerja dalam memberikan pelayanan kepada masyarakat dan tidak terbuka dalam menjalankan tugasnya. Sehingga dapat memperlambat pelayanan dan dapat dinilai pelayanan yang buruk walaupun dari permasalahan yang kecil saja.

Berlakunya Undang-Undang Nomor 23 Tahun

2014 tentang Pemerintah Daerah bahwa penyelenggaraan pemerintah daerah diarahkan untuk mempercepat terwujudnya kesejahteraan masyarakat melalui peningkatan pelayanan, pemberdayaan dan peran serta masyarakat, serta peningkatan daya saing daerah dengan memperhatikan prinsip demokrasi, pemerataan, keadilan, dan kekhasan suatu daerah dalam sistem Negara Kesatuan Republik Indonesia.

Dalam Undang-Undang tersebut masyarakat menghendaki suatu penyelenggaraan pemerintah yang bersih dan berwibawa serta berwawasan pelayanan kepada masyar akat agar tidak adanya keluhan dalam rendahnya produktifitas kerja dan disiplin dari pegawai dalam memberikan pelayanan kepada masyarakat.

Dalam rangka meningkatkan pelayanan maka perlukan pengembangan pegawai untuk mencapai kualitas kerja yang baik dan terarah sesuai prosedur yang telah ditetapkan agar tidak berpengeruh terhadap buruknya suatu pelayanan dalam sebuah organisasi. Akan tetapi kenyataan yang terjadi masih banyak pelayanan disuatu organisasi atau lembaga belum menjalankan sesuai prosedur dan kualitas dari pelayanan tersebut sangat jauh dari kata baik.

Tujuan dari penelitian ini adalah untuk mengetahui kualitas kinerja pegawai dalam memberikan dan meningkatkan pelayanan Di Dinas Penanaman Modal dan Pelayanan Terpadu Satu Pintu Kota Palangka Raya.
Menurut Hasibuan (2002: 160), “Kinerja adalah hasil kerja yang dicapai seseorang dalam melaksanakan tugas-tugasnya atas kecakapan, usaha dan kesempatan. Berdasarkan paparan diatas kinerja adalah suatu hasil yang dicapai seseorang dalam melaksanakan tugas-tugas yang didasarkan atas kecakapan, pengalaman dan kesungguhan serta waktu menurut standar dan kriteria yang telah ditetapkan sebelumnya". Sementara itu,Menurut Fuad Mas'ud (2004) menyatakan ada lima indikator kinerja pegawai secara individu, yang dapat dijelaskan sebagai berikut :

I. Kualitas

2. Kuantitas

3. Ketepatan Waktu

4. Efektivitas

5. Komitmen Kerja

\section{METODOLOGI}

Metode penelitian yang digunakan adalah metode penelitian kualitatif Karena metode ini merupakan sebuah menggambarkan, menjelaskan dan mendeskripsikan suatu masalah.

Proses penelitian kualitatif ini melibatkan upaya-upaya penting, seperti mengajukan pertanyaanpertanyaan dengan prosedur-prosedur tertentu. Laporan akhir penelitian ini memilikki struktur atau kerangka yang fleksibel.

Teknik pengumpulan data yang digunakan dalam penelitian ini yaitu : I) Wawancara, Pihak yang di wawancara pada penelitian adalah Kepala Bagian Pengaduan, Kepala Bidang Pelayanan, Pegawai Pengaduan dan dari masyarakat pengguna layananKota Palangka Raya. 2) Obsevasi, Observasi pada penelitian ini dilakukan untuk melihat bagaimana kinerja pegawai dalam meningkatkan pelayanan di dinas penanaman modal dan pelayanan satu pintu kota palangka raya. 3)Dokumentasi, Dokumentasi ini berup foto, profil pegawai, struktur organsiasi dan tupoksi, regulasi dan dokumen terkait yang mendukung. 


\section{HASIL DAN PEMBAHASAN}

Aparatur pemerintah sebagai abdi negara dan memberikan pelayanan kepada masyarakat harus selalu mengutaman kualitas kinerjanya untuk pelayanan yang baik dan berkualitas sehingga terciptanya kesejahteraan sosial yang tercantum dalam pancasila pada sila kelima, yaitu keadilan sosial bagi seluruh rakyat indonesia.

Pada hakikatnya sebuah pelayanan serta kualitas kinerja pegawai yang berkualitas sangatlah dibutuhkan oleh masyarakat dalam setiap urusannya pada suatu organisasi pemerintahan. Begitu pula seharusnya pelayanan yang diberikan oleh aparatur atau petugas di Kantor Penanaman Modal dan Pelayanaan Satu Pintu Kota Palangkaraya terutama pada bagian pelayanan pembuatan izin-izin seperti IMB yang selalu menjadi masalah karena kurang tepat waktu. Kualitas kinerja dalam pelayanan yang baik yang diberikan kepada masyarakat itu juga agar terwujudnya visi, misi dan tujuan organisasi tersebut.

Dalam menunjang pelayanan yang berkualitas hal ini juga dapat didukung oleh fasilitas fisik yang meliputi, ruangan yang nyaman, kursi tunggu yang memadai, pendingin ruangan/AC, meja kerja petugas, toilet umum, banner alur pelayanan yang berfungsi untuk membantu para pemohon dalam pengurusan izin.

Sehingga untuk mengetahui kinerja pegawai selain melakukan observasi peneliti juga melakukan wawancara dengan dinas terkait. Dalam wawancara peneliti mengacu pada Teori Fuad Mas'ud dengan berdasarkan lima indikator yaitu : kualitas, kuantitas, ketepatan waktu, efektivitas, dan komitmen kerja. Berikut ini hasil wawancara peneliti dengan informan.

I. Kualitas

Kualitas, tingkat dimana hasil aktivitas yang dilakukan mendekati sempurna dalam arti menyesuaikan beberapa cara ideal dari penampilan aktivitas maupun memenuhi tujuan yang diharapkan daru siatu aktivitas. Sebuah pelayanan yang baik dapat diukur bagaimana cara kinerja pegawainya tersebut memberikan suatu pelayanan. Karena kualitas menjadi suatu tolak ukur dalam menilai suatu pelayanan dan kinerja pegawai. Kualitas dapat dihasilkan dari aktivitas atau pelayanan yang dilakukan oleh pegawai yang hampir mendekati sempurna yang kekurangannya masih bisa dihitung pelayanan yang dimaksud adalah pelayanan yang diberikan sesuai dengan apa yang menjadi SOP atau acuan para pegawai dalam memberikan pelayanan terhdap pemohon dalam memenuhi kebutuhan dari pemohon atau masyarakat. Aktivitas pegawai sudah dikatakan cukup baik dengan jumlah SDM yang bisa dibilang dalam kekurangan, pegawai sudah memaksimalkan kinerja mereka dengan prosedur yang sudah ditetapkan.

Aktivitas pegawai sudah dikatakan cukup baik dengan jumlah SDM yang bisa dibilang dalam kekurangan, pegawai sudah memaksimalkan kinerja mereka dengan prosedur yang sudah ditetapkan.

2. Kuantitas

Kuantitas, jumlah yang dihasilkan dalam istilah sejumlah unit, jumlah siklus aktivitas yang diselesaikan. Kinerja pegawai dilihat dari kuantitasnya yaitu, bagaimana pegawai melaksanakan tugasnya sesuai dengan tugas yang diberikan serta bagaimana pegawai tersebut mengembangkan kreativitas kerja guna menunjang tingkat keberhasilan suatu tugas yang diberikan. Adapun kendala yang sering dihadapi oleh pegawai dalam melaksanakan tugasnya khususnya bidang pelayanan, bagaimana setiap pegawai dituntut untuk selalu melaksanakan tugas ataupun menyelesaikan tugas dengan tepat sesuai dengan waktu yang ditentukan. Akan tetapi yang kita ketahui bahwa dalam melaksanakan tugas 
memberikan pelayanan masih terdapat masalah yang dialami baik itu teknis maupun non teknis, seperti dalam memberikan pelayanan alat penunjang tidak memadai ataupun desakan dari masyarakat yang ingin mendapatkan pelayanan yang cepat tetapi dalam pengurusan berkas mereka tidak lengkap, hal ini menjadi salah satu masalah yang dialami pegawai sehingga mengurangi kinerja yang diberikan kepada hasil atau visi misi kantor dalam pelayanan.

Dalam melaksanakan tugas memberikan

pelayanan masih terdapat masalah yang dialami baik itu teknis maupun non teknis, seperti dalam memberikan pelayanan alat penunjang tidak memadai ataupun desakan dari masyarakat yang ingin mendapatkan pelayanan yang cepat tetapi dalam pengurusan berkas mereka tidak lengkap, hal ini menjadi salah satu masalah yang dialami pegawai sehingga mengurangi kinerja yang diberikan kepada hasil atau visi misi kantor dalam pelayanan.

\section{Ketepatan Waktu}

Ketepatan waktu, tingkat suatu aktivitas diselesaikan pada wkatu yang diinginkan dilihat dari sudut koordinasi dengan hasil output serta memaksimalkan waktu yang tersedia untuk aktivitas orang lain. Penilaian kinerja pegawai terhadap ketepatan waktu masih terdapat kendala yaitu masih terdapat pegawai yang kurang disiplin dilihat dari waktu masuk jam kerja. Serta kerjasama antar pegawai yang masih dianggap kurang baik antar pegawai maupun pegawai dengan pimpinann ini dilihat dari masih terdapatnya pegawai yang kurang memahami instruksi dari pimpinan serta masih saling mengharapkan pekerjaan ditangani oleh pegawai lainnya yang menyebabkan tugas atau pekerjaan yang diberikan tertunda, serta pekerjaan yang dilakukan oleh pegawai masih terkesan kaku karena pegawai masih kebingungan untuk mengambil keputuasan dalam melaksanakan tugas. Hal tersebut terjadi karena masih kurangnya komunikasi antar pegawai dan pegawai dengan pimpinan.

Penilaian kinerja pegawai terhadap ketepatan waktu masih terdapat kendala yaitu masih terdapat pegawai yang kurang disiplin dilihat dari waktu masuk jam kerja. Serta kerjasama antar pegawai yang masih dianggap kurang baik antar pegawai maupun pegawai dengan pimpinann ini dilihat dari masih terdapatnya pegawai yang kurang memahami instruksi dari pimpinan serta masih saling mengharapkan pekerjaan ditangani oleh pegawai lainnya yang menyebabkan tugas atau pekerjaan yang diberikan tertunda, serta pekerjaan yang dilakukan oleh pegawai masih terkesan kaku karena pegawai masih kebingungan untuk mengambil keputuasan dalam melaksanakan tugas.

4. Efektivitas

Efektivitas, tingkat pengguna sumber daya manusia dalam organisasi dengan maksud menaikkan keuntungan atau mengurangi kerugian dari setiap unit dalam pengguna sumber daya manusia. Yang kita lihat adalah sumber daya manusia dikantor tersebut masih kurang apalagi dalam bidang pelayanan. Kekurangan SDM dapat mempengaruhi tingkat kepasan masyrakat terhadap pelayanan yang diberikan pegawai. Karena dari segi kualitas kinerja saja mereka sangatlah kurang apalagi dalam membrikan pelayanan kepada mastarakat. Akan tetapi bisa saja terjadi dalam pelayanan mereka memberikan yang terbaik dengan cara kerja sama walupun mereka kekurangan SDM, kerja sama yang dilakukan saling mengisi dalam menjalankan tugas. Sumber daya manusia dikantor tersebut masih kurang apalagi dalam bidang pelayanan. 
Kekurangan SDM dapat mempengaruhi tingkat kepasan masyrakat terhadap pelayanan yang diberikan pegawai. Karena dari segi kualitas kinerja saja mereka sangatlah kurang apalagi dalam membrikan pelayanan kepada mastarakat. Akan tetapi bisa saja terjadi dalam pelayanan mereka memberikan yang terbaik dengan cara kerja sama walupun mereka kekurangan SDM, kerja sama yang dilakukan saling mengisi dalam menjalankan tugas.

5. Komitmen Kerja

Komitmen kerja, tingkat dimana karyawan mempunyai komitmen kerja dengan kantor dan tanggung jawab kepada kantor. Dalam suatu kinerja memiliki SOP yang telah dibuat dalam perwali. Sebagian pegawai belum menjalankan tugasnya dan kurangnya bertanggung jawab dalam tugas yang diberikan. Karena masih ada pegawai yang mengharapkan tugasnya dikerjakan oleh pegawai lainnya sehingga membuat pegawai kurang bertanggung jawab.

Sebagian pegawai belum menjalankan tugasnya dan kurangnya bertanggung jawab dalam tugas yang diberikan. Karena masih ada pegawai yang mengharapkan tugasnya dikerjakan oleh pegawai lainnya sehingga membuat pegawai kurang bertanggung jawab.

Faktor pendukung yang ada di Dinas Penanaman Modal Pelayanan Terpadu Satu Pintu yaitu Saling memberikan semangat dan saling menyemangit antar pegawai dan menjalankan tugasnya berbagi karena kurangya sumber daya manusia tadi dapat saling membantu dalam menjalankan tugasnya dan menutupi kekurangan dari pekerjaan yang belum selesai serta berusaha memberikan pelayanan yang terbaik bagi pengguna layanan yang membutuhkan pelayanan. Inilah yang menjadi salah satu faktor yang mendorong agar kinerja pegawai memberikan semaksimal mungkin dalam memberikan pelayanan terhadap masyarakat.

Selanjutnya factor penghambat dalam meningkatkan pelayanan kualitas pegawai di Dinas Penanaman Modal Pelayanan Terpadu Satu Pintu yaitu dalam proses meningkatkan pelayanan kualitas pegawai sanglah berperan penting karena dari hal kecil yang dilakukan seorang pegawai dalam menjalankan tugasnya atau dalam memberikan pelayanan bisa dinilai langsung oleh masyarakat dan pengaruhnya sangatlah besar terhadap kinerja pegawainya. Hal ini dapat dikatakan dalam proses pelayanan masih ada faktor-faktor kendala yang dapat mengahmbat jalannya pelayanan diantaranya, sumber daya manusia atau pegawainya yang kurang terutama dalam bidang pelayanan yang dibuktikan dari pegawai kurang menguasai bidang pelayanan dan keterlambatan waktu yang diberikan dalam menjalankan tugasnya banyak yang tidak sesuai.

\section{KESIMPULAN}

Berdasarkan uraian pada hasil penelitian dan pembahasan, dapat ditarik kesimpulan sebagai berikut :

I. Kinerja pegawai dalam meningkatkan pelayanan di DPM-PTSP Kota Palangkaraya masih belum optimal, dilihat dari lima indikator yaitu Kualitas, Kuantitas, Ketepatan Waktu, Efektivitas, dan Komitmen Kerja.

a. Kualitas, kinerja pegawai sudah dikatakan cukup baik dalam menjalankan tugas dan sesuai prosedur tetapi masih belum optimal.

b. Kuantitas, masih adanya kekurangan dalam memberikan pelayanan baik itu teknis maupun non teknis.

c. Ketepatan Waktu, kinerja pegawai sudah cukup baik akan tetapi masih ada kendala yaitu dalam ketepatan waktu masih kurang karena pegawainya kurang memahami instruksi dan bekerja masih saling 
mengharapkan pegawai lain dan belum bisa bertanggung jawab terhadap tugasnya.

d. Efektivitas, kekurangan sumber daya manusia atau pegawai inilah salah satu masalah dalam sebuat kualitas kinerja, karena dapat mempengaruhi tingkat kepuasan masyarakat dalam memberikan pelayanan.

e. Komitmen Kerja, masih ada pegawai yang mengharapkan tugasnya dikerjakan oleh pegawai lain ini yang menyebabkan sebagian pegawai belum bisa bertanggung jawab dengan apa yang dikerjakannya.

2. Faktor-faktor kendala yang dapat mengahmbat jalannya pelayanan diantaranya, sumber daya manusia atau pegawainya yang kurang terutama dalam bidang pelayanan yang dibuktikan dari pegawai kurang menguasai bidang pelayanan dan keterlambatan waktu yang diberikan dalam menjalankan tugasnya banyak yang tidak sesuai. Selain faktor penghambat ada juga faktor pendukung yaitu saling memberikan semangat dan saling menyemangit antar pegawai dan menjalankan tugasnya berbagi karena kurangya sumber daya manusia tadi dapat saling membantu dalam menjalankan tugasnya dan menutupi kekurangan dari pekerjaan yang belum selesai serta berusaha memberikan pelayanan yang terbaik.

\section{SARAN}

Berdasarkan kesimpulan tersebut, maka dapat diberikan saran-saran berikut :

I. Dinas Penanaman Modal dan Pelayanan Terpadu Satu Pintu sebaiknya meningkatkan kinerja pegawainya dengan mengikuti prosedur serta dengan menambah sumber daya manusia atau pegawai.

2. Dinas Penanaman Modal dan Pelayanan Terpadu Satu Pintu perlu mengadakan pelatihan terhadap pegawai layanan yang belum mampu mengoperasikan alat bantu dalam proses pelayanan. Selain itu meningkatkan memberikan pelayanan sebagai alat penunjang.

3. Pegawai di Dinas Penanaman Modal dan Pelayanan Terpadu Satu Pintu sebaiknya saling mengingatkan dalam menjalankan tugas yang telah diberikan serta lebih berani lagi dalam mengambil keputusan dalam melaksanakan tugas.

4. Dinas Penanaman Modal dan Pelayanan Terpadu Satu Pintu sebaiknya meningkatkan jumlah sumber daya manusia atau pegawai khususnya bagian pelayanan agar lebih optimal lagi dalam memberikan pelayanan kepada masyarakat.

5. Pegawai di Dinas Penanaman Modal dan Pelayanan Terpadu Satu Pintu sebaiknya lebih bertanggung jawab atas tugasnya masing-masing tanpa mengharapkan pegawai lainnya.

\section{REFERENSI}

Fendeli, Chafid. 2018. Analisis Mengenai Dampak Lingkungan Pembangunan Pelabuhan. Gadjah Mada Universiti Press, Yogyakarta.

Flippo, Edwin. 1995. Manajemen Personalia, Edisi Keen am, Jakarta: Erlagga.

Fuad Mas'ud. 2004. "Survai Diagnosis Organisasional," Badan Penerbit Universitas Diponegoro, Semarang.

Gunawan, Iman. 20I4. Metode penelitian kualitatif (teori dan praktik). Jakarta:Bumi Aksara

Hasibuan, Malayu. 2002. Manajemen Sumber Daya Manusia . Bumi Aksara. Jakarta.

Joko Widodo. 20I3. Analisis Kebijakan Publik. Malang. Bayumedia Publishing.

Moloeng, Lesa. J.2004. Metode penelitian kualitatif. Bandung : P.Remaja rosdakarya.

Pasolong, Harbani. 2013. Metode Penelitian Administrasi Publik. Bandung: Alfabeta 
Patilima, Hamid. 2007. Metode penelitian kualitatif. Bandung: Alfabeta

Peraturan Daerah Kota Palangka Raya Nomor 17

Tahun 2015 Tentang Perizinan dan non perizinan Badan Penanaman Modal dan Pelayanan Terpadu Satu Pintu.

Sugiyono. 2013. Metode penelitian Administrasi di lengkapi dengan metode $P$ dan D. Bandung: Alfabeta. 